\title{
JUDICIAL PRACTICES IN SELECTED STATES IN CASES OF LEGAL LIABILITY OF AUCTION PORTALS FOR COUNTERFEIT GOODS
}

\author{
[Soudní praxe ve vybraných státech v případech právní odpovědnosti aukčních \\ portálů za prodej padělků]
}

\author{
Tomáš Gongol ${ }^{1}$ \\ ${ }^{1}$ Slezská univerzita, Obchodně podnikatelská fakulta, Univerzitní nám. 1934/3,73340 Karviná \\ Email:gongol@opf.slu.cz
}

\begin{abstract}
The problem with verification of origin of goods in the online environment has resulted in an increase of the sale of counterfeit goods and general abuse of Trademarks. The following article deals with the question of legal liability of Internet auction portals, which have become a distribution and sales point of counterfeit goods. With regard to the topic of the article, which falls within the scope of the rarely codified are of the operation of law on the Internet there are particularly compared approaches both European and North American judicial practice. Courts on the both continents have repeatedly solved the problems of Internet portals as information society service providers. The subject of particular interest is globally active auction site eBay, which has been the subject of many disputes worldwide.
\end{abstract}

Keywords: counterfeit goods, internet regulation, online auction, Trademark.

JEL classification: $\mathrm{K} 24$

Doručeno redakci: 28.10.2016; Recenzováno: 2.11.2016; 10.11.2016; Schváleno k publikování: 30.11.2016

\section{Úvod}

Ochranná známka pomáhá vlastníkovi odlišit výrobky nebo služby od jiných soutěžitelů na trhu, snižuje tak riziko zmatení spotřebitele co do původu, kvality produktu a vlastníkovo úsilí a finanční prostředky vložené do vytvoření silné ochranné známky, odměňuje věrností zákazníků (Carrol a Ahuvia 2006). V kontextu internetového obchodování Otim a Grover (2010) zjišt’ovali vztahy mezi silou ochranné známky a tendencí spotřebitelů vyhledávat a verifikovat informace před rozhodnutím provést nákup na internetu. Pro ochranné známky jako nositele informací signalizující kvalitu zboží, služby či jejich původce platí, že potřeba spotřebitelů provést hlubší vyhledávání a ověrování informací před nákupem produktu se snižuje s tím, jak se zvyšuje síla ochranné známky. Uvedené v důsledku znamená, že omezená míra vyhledávání a verifikování informací vede nakonec ke zvyšování př́ijmů narušitele práv k ochranné známce a naopak snižování př́ijmů vlastníka ochranné známky. Vychází se zejména ze skutečnosti, že jak spotřebitelé, tak i obchodníci jednají rozumně a hodnotí produkty podle jim dostupných informací. A protože je internet v tomto ohledu „virtuálním“ tržištěm, spotřebitelé v podstatě nemohou odlišit od sebe výrobky, které práva k ochranným známkám porušují, zejm. padělky, a které ne. Prodejci padělaného zboží udělají vše proto, aby jejich výrobky byly stejně věrohodné jako jejich originály. Vlastníkovi ochranné známky tak vzniká ztráta, jejíž původ má dva zdroje:

1. trh podhodnotí cenu některých kvalitních výrobků (viz dále např. Tiffany vs. eBay),

2. osoba porušující práva k ochranným známkám (zejm. padělatel) zachytí část tržního podílu díky parazitování na ochranné známce.

Snížené náklady na prodej zboží přes internet umožňují téměř každému, aby prodával na online tržištích. Obzvláště zřejmé to je v případě aukčních portálů jako jsou aukro.cz, bazar.cz, nebo světově známý eBay.com. Problém s verifikací původu zboží v online 
prostředí měl za následek nárůst prodeje padělků a obecně zneužití obchodních označení, včetně ochranných známek (Otim a Grover 2010). Podle Europolu (2015) ${ }^{1}$ se internet stal největším distribučním a prodejním místem umožňujícím prodej padělaného zboží. Mezi zmiňované výhody patř́ přesah různými státními jurisdikcemi, možnost kdykoliv a jednoduše „zavřít obchod“, dostupnost kdykoliv a odkudkoliv atd. Také podle zprávy Mezinárodní obchodní komory (ICC, 2011)2 bylo odhadováno, že v roce 2015 mezinárodní obchod s padělky dostoupá výše 1.77 bilionu USD. To je téměř trojnásobný nárůst oproti roku 2008. I z této zprávy vyplývá, že zásadní vliv na mezinárodní obchod s padělky má stále snadnější př́stup $\mathrm{k}$ internetu.

Tato skutečnost je ovlivněna také poptávkou spotřebitelů po „značkovém“ zboží, jako symbolu luxusu a př́slušnosti k určité (elitní) skupině lidí, jak popisuje Abel (1990). Tato skupina spotřebitelů ví, že kupuje padělané zboží a přesto mu dává přednost před zbožím originálním. Do velké míry anonymní prostředí internetu jim k tomu dává větší prostor. Zatímco známkové právo staví tradičně na vztahu obchodník (prodejce zboží chráněného ochrannou známkou) a spotřebitel (B2C), obchody, které jsou realizovány prostřednictvím internetu, tento tradiční vztah posouvají často do úrovně spotřebitel - spotřebitel $(\mathrm{C} 2 \mathrm{C})$. Takové transakce jsou typicky realizovány právě prostřednictvím výše zmíněných aukčních portálů.

Uvedenou situaci způsobuje zejména vysoká míra anonymity, kterou umožňuje internet, resp. chybějící fyzická lokalizace obchodu a vedle toho také globální dosah internetu, který překračuje hranice působnosti národních právních řádů. $\mathrm{V}$ době před masivním rozšiřrením internetu se mezinárodního obchodu účastnili v převážné míře velké společnosti obchodující $\mathrm{s}$ velkým objemem zboží. Tyto subjekty byly $\mathrm{v}$ celku dobře identifikovatelné a $\mathrm{v}$ př́padě soudních sporů byl poměr nákladů a výnosů rozumný (Vetter 2006). V př́padě elektronického obchodování je situace poměru nákladů a výnosů komplikovanější. Jednak je u řady mezinárodních obchodů složité nalézt a dopadnout konkrétního podvodníka (a tedy zajistit také náhradu nákladů řízení) a navíc je často obchodováno v malých objemech, typicky segmentově orientovaných, malých prodejců. $V$ těchto př́ípadech je efektivita soudního řízení a výkonu rozhodnutí natolik malá, že poškozeného od podání žaloby zcela odradí. V důsledku toho se snižuje také vymahatelnost práva duševního vlastnictví. Jak dokazuje Jennings (1989), padělání bylo vždy problémem, nicméně s nástupem internetu se jeho míra neúměrně zvýšila (viz výše uvedené zprávy). V důsledku toho dochází ke snižování síly ochranné známky, jsou ohroženy investice, které byly spojeny s vybudování její známosti, příp. dobrého jména ochranné známky, a navíc se vlastníkovi ochranné známky snižuje podíl na trhu, čímž v důsledku přichází o př́ijmy. Internet prohlubuje tyto problémy, protože náklady na tvorbu duplikátů loga nebo ochranné známky a jejich zobrazování na webových stránkách jsou nízké (Grover a Ramanlal 2004). Např́íklad barevně syté logo vynikne na monitoru stejně u padělku, jako u originálu, a to bez dalších nákladů, které jsou potřebné v případě použití tradičně tištěných médií. Internet $\mathrm{v}$ důsledku výše popsaného snižuje informační hodnotu (funkci) vtělenou do ochranné známky (Otim a Grover 2010).

Ve věci prodeje padělků na internetu zejména prostřednictví aukčních portálů bylo vydáno v EU i USA řada rozhodnutí. Předmětem sporů bylo porušování ochranných známek zejména

\footnotetext{
${ }^{1}$ Situation Report on Counterfeiting in the European Union 2015. Dostupné z https://oami.europa.eu/ohimportal/documents/11370/80606/2015+Situation+Report+on+Counterfeiting+in+the+ EU [vid. 11.10.2016]

${ }^{2}$ Global Impacts Study. Dostupné z http://www.iccwbo.org/Advocacy-Codes-and-Rules/BASCAP/ BASCAPResearch/Economic-impact/Global-Impacts-Study/ [vid. 10.9.2016]
} 
chránících luxusní zboží (např. Tiffany, L`Oreal, Louis Vuitton). Přístup k řešení těchto sporů se v mnoha prŕípadech lišil. Zatímco rozhodnutí v USA (Tiffany v. eBay) a některých evropských státech jako Belgie (Lancôme Parfums et Beaute \& Cie v. eBay International AG) nebo Německo (Rolex $S A$ v. eBay Inc) neshledaly internetové aukční portály odpovědné za porušování práv k ochranným známkám, rozhodnutí některých soudů ve Francii konstatovaly opak a uložily povinnost náhrady škody prodejci padělků a spolu s ním také aukčnímu portálu.

\section{Rozhodovací praxe německých soudů}

Problematika internetových aukčních portálů byla předmětem několika rozhodnutí $\mathrm{BGH}$. Ve všech uvedených sporech byl jednou ze stran sporu výrobce luxusních hodinek Rolex SA. Prvním z těchto sporů byl Rolex SA v. Ricardo.de (1 ZR 304/01) ze dne 11.3.2004 vedený $\mathrm{s}$ aukčním portálem Ricardo.de, na kterém byly mimo jiné prodávány také hodinky označené ochrannou známkou Rolex a druhý spor vedený s eBay Inc. (I ZR 35/04). V obou př́padech šlo o prodej padělků originálních výrobků, přičemž ceny za padělané výrobky byly mnohem nižší než za originály a v několika případech byly výslovně označeny jako napodobenina nebo replika. Skutkový základ je zde velice podobný sporu Tiffany v. eBay (viz dále soudní rozhodnutí v USA).

Soud $\mathrm{v}$ obou případech zkoumal přímé a nepřímé porušení práv $\mathrm{k}$ ochranným známkám a odpovědnost z civilních deliktů aukčních portálů Richardo a eBay a její omezení. Pokud jde o odpovědnost prodávajících, soud konstatoval jejich odpovědnost za porušování práv o ochranných známkách na základě oddílu 14 německého zákon o ochranných známkách (Markengesetz). Soud zde zdůraznil, že k porušení práv k ochranné známce dochází i přesto, že kupující věděl, vzhledem k ceně a označení replika, že nekupuje originální výrobek. V souladu s rozhodnutím Soudního dvora Evropské unie (dále jen SDEU) Arsenal Fotball Club v. Reed soud uvedl, že aplikace oddílu 14 zákona nevyžaduje prokázání záměny v konkrétním případě, ale stačí, pokud zde existuje abstraktní nebezpečí záměny na straně veřejnosti. Také podle německého práva je požadováno užití v obchodním styku, které soud konstatoval na straně prodávajících vzhledem k opakovaným aktivitám tohoto druhu a také vysokému hodnocení kupujících na jejich uživatelských profilech, které takové aktivity dokazují. Ovšem zdůraznil také, že ojedinělý prodej, který není součástí širší obchodní aktivity uživatele aukčního portálu, takto posuzován být nemůže.

Pokud jde o odpovědnost samotných aukčních portálů, soud odmítl jejich prímou odpovědnost za porušení práv k ochranným známkám s odůvodněním, že tito provozovatelé sami zboží neprodávají, nedávají je do oběhu ani je nepoužívají v reklamě. Pokud jde o sekundární, neprrímou odpovědnost aukčních portálů, ani zde soud neshledal důvody pro její uplatnění a to $\mathrm{z}$ důvodu chybějícího zavinění. Z pohledu sekundární odpovědnosti tedy BGH došel ke stejným závěrům a odůvodněním jako v př́ípadě soudů USA ve věci Inwood Labs v. Ives Labs. (viz dále), tedy neexistence sekundární odpovědnosti z důvodu nedostatku úmyslu, protože eBay měl pouze „obecné povědomí" o porušování práv k ochranným známkám na svém aukčním portále. Podle BGH byl tento nedostatek vědomí dán automatickým systémem zadávání zboží do prodeje bez známosti konkrétního obsahu zadávaného prodejcem. Důvodem, proč německý BGH kladl malý význam obecnému povědomí pro účely založení sekundární odpovědnosti, spočívá dle Sounderse a Berger-Waliiserové (2011) v německé koncepci störerhaftung (narušitel), jejímž základem jsou ustanovení o odpovědnosti za civilní delikty upravené v $\S 823$ Bürgerliches Gesetzbuch (BGB). Podmínkou uplatnění konceptu störerhaftung na sekundární odpovědnost aukčních portálů totiž je, aby narušitel aniž by sám porušoval nebo se př́mo účastnil porušování práv, kauzálně a vědomě přispíval adekvátním 
způsobem k porušování chráněného práva a byl v pozici, kdy porušování může zabránit. Aby mohl být koncept sekundární odpovědnosti skutečně aplikován na aukční portály, musely by mít dle BGH povinnost monitorovat aktivity, které jsou jejich prostřednictvím realizovány. Pokud by takovou povinnost porušil, nesly by odpovědnost. Soud nicméně ihned doplnil, že monitoring takových aktivit (každé nabídky na portálu) není možné po aukčních portálech požadovat. Takový požadavek by mohl být zásadním problémem pro celý tento obchodní model a byl by v rozporu se Směrnicí o elektronickém obchodu. Nicméně, v př́padě, kdy je internetový aukční portál informován o porušení práv k ochranné známce, musí nejen okamžitě zamezit přístup k aktuální nabídce, ale také přijmout taková opatření, která zajistí, aby se podobné porušení ochranné známky znovu neopakovalo. Uvedené stanovisko BGH je označováno jako pravidlo hlavní podobnosti a je podle něj vyžadováno, aby aukční portál poté, kdy byl informován, nabídl speciální postup, který nejen odstraní konkrétní př́ípad nabídky zboží porušující práva k ochranným známkám, ale aby kontroloval nové nabídky použitím zvláštního filtru a smazal takové, které budou podobně závadné.

Můžeme uzavřít, že nároky na náhradu škody vznesené proti internetovým aukčním portálům v Německu, založené na přímé či nepřímé odpovědnosti za porušování práv k ochranným známkám jsou z důvodu nedostatku zavinění zamítnuty. Soud nicméně ukládá v těchto př́padech povinnost aukčnímu portálu dále monitorovat, detekovat a odstraňovat budoucí zásahy do ochranné známky třetími subjekty. Podmínkou této monitorovací povinnosti je, že porušení práv k ochranné známce je zřejmé a podstatně (v jádru) podobné těm, které jsou známé aukčnímu portálu. Co je zřejmým porušením práv k ochranným známkám, stejně jako podobnost prrípadů zůstalo dále soudem nevyjasněné. V rozhodnutí Kinderhochstühle im Internet (I ZR 139/08) ze dne 22. července 2010 přeci jen BGH specifikoval, že aukční portál má povinnost filtrovat nové nabídky technickými prostředky a kontrolovat manuálně podezřelý obsah, nicméně nemá povinnost manuálně vyhledávat porušování práv $\mathrm{k}$ ochranným známkám $\mathrm{v}$ př́padech, které nedetekoval technický filtrovací program. Je nutné připomenout, že technická proveditelnost bude závislá na technologickém vývoji a proto se tento požadavek bude v čase měnit, proto soud zřejmě nemohl stanovit bližší standardy.

Pokud jde o postavení aukčního portálu jako poskytovatele služeb informační společnosti, BGH bez hlubšího rozboru stanovil, že aukční portál je za takového poskytovatele považován s ohledem na skutečnost, že nabídka této služby je dostupná on-line a je založená na automatickém zpracování. Francouzské soudy se odůvodněním zabývaly hlouběji.

\section{Rozhodovací praxe francouzských soudů}

Ve Francii a nejen v ní, jsou zřejmě nejznámější nároky několika vlastníků ochranných známek na luxusní zboží vznesené v roce 2008 ve společném řízení $L V M H$ v. eBay. Šlo o vlastníky ochranných známek Louis Vuitton, Christina Dior a dalších. Skutkový stav v těchto sporech byl velmi podobný sporům v Německu, ale na rozdíl od německých rozhodnutí, byla v těchto sporech vlastníkům ochranných známek uznána také náhrada škody v celkové výši 38,6 milionů EUR. Odvolací soud poté snížil částku na 5,7 milionu.

Francouzské spory se na rozdíl od německých (a jak bude dále vysvětleno, i amerických) nesoustřed'ují na sekundární odpovědnost za porušování práv k ochranným známkám nebo odpovědnost za civilní delikty, ale na otázku, jestli je eBay patří mezi poskytovatele služeb informační společnosti a tedy, jestli se na ně vztahuje právní úprava omezené odpovědnosti v souladu se Směrnicí o elektronickém obchodu. Také ve francouzském zákoně o duševním vlastnictví (Code de la Propriété Intellectuelle) najdeme ustanovení o sekundární odpovědnosti, ovšem pouze ve vztahu k patentům a nikoliv k ochranným známkám. 
Francouzský soud v Troyes v rozhodnutí ze dne 4.6.2008 ve sporu o ochrannou známku Hermès (06/02604) shledal eBay odpovědný za přímé porušení práv k ochranným známkám a to z toho důvodu, že nedodržel svou povinnost, aby nikdo nepoužil portál k protiprávnímu jednání. Na rozdíl od soudů v USA, jak uvedeme níže, totiž soud první instance v Troyes neshledal verifikační, automatickou detekci (VeRO) padělků dostatečnou, protože se dle mínění soudu prodejci přizpůsobili tomuto filtru tak, že jsou schopni ho obejít. Dle mínění soudu se eBay má zaměřit na to, aby přinutil prodávající identifikovat zboží tím, že budou zveřejňovat kód výrobku, sériové číslo, certifikát původu apod. Podle odůvodnění tohoto rozhodnutí musí být z povahy své činnosti eBay chápán jako poskytovatel služeb informační společnosti ve smyslu čl. 14 Směrnice 2000/31/ES, protože ukládá informace svých uživatelů bez vlivu na jejich. Nicméně, dle soudu, obchodní model eBay jde nad rámec pouhého hostingu, protože dává uživatelům další nástroje na propagaci jejich zboží a sám se také propagace účastní. V červnu 2010 uvedené rozhodnutí potvrdil také odvolací soud v Remeši.

Také $\mathrm{v}$ př́padě $L V M H v$. eBay dospěl soud $\mathrm{k}$ podobným závěrům jako $\mathrm{v}$ případě ochranné známky Hermès. Podle Obchodního soudu v Paříži, eBay zásadním způsobem pomáhá při prodeji a marketingu padělaného zboží třetími osobami. Navíc, díky označení "napodobenina" nebo "replika" a nízkým cenám, muselo být eBay zřejmé, že zde dochází k porušování práv k ochranným známkám. Své rozhodnutí opřel o § 1383 a 1384 Code Civil, na základě kterých dovodil, že nesou odpovědnost i ti, kdo nezajistí, aby jejich jednání nezabránilo vzniku takových aktivit, které porušují práva jiných. Soud proto uložil eBay povinnost náhrady škody na základě nedbalosti a závažného opomenutí.

Dalším sporem, vedeným tentokrát před Tribunal de Grande Instance byl spor mezi L 'Oréal SA v eBay France SA (07/11365). Na rozdíl od předchozích, výše uvedených sporů řešených před francouzskými soudy $\mathrm{v}$ tomto případě soud přiznal eBay výjimku $\mathrm{z}$ odpovědnosti za poškozování práv třetích osob poskytovateli služeb informační společnosti s tím, že rozšíření internetu a komplexnosti elektronického obchodování umožňuje rozlišit tzv. primární (hlavní) a sekundární obchodní aktivity poskytovatelů hostingových služeb tak, jak to bylo uvedeno $\mathrm{v}$ předchozích rozhodnutích. Proto soud rozhodl, že poskytovatelům takových služeb musí být zajištěna výjimka $\mathrm{z}$ odpovědnosti pro oba typy aktivit v souladu s článkem 14 Směrnice 2000/31/ES i pro obchodní aktivity. Proto soud odmítl nárok L’Oréal proti eBay za porušování práv $\mathrm{k}$ ochranné známce $\mathrm{v}$ souvislosti $\mathrm{s}$ prodejem padělků uživatelů aukčního portálu. Zároveň uvedl, že podmínkou uplatnění výjimky je omezení aktivit eBay na uložení informací uživatelů jeho služeb a umístnění jejich nabídek na internetový portál. Na aktivity nad rámec toho (např. inzerce) se výjimka nevztahuje.

Uvedená problematika se nakonec v Evropě dostala až k SDEU jako otázka na výklad př́slušných norem ve sporu mezi společnostmi L Oreal SA v. eBay International AG (C-324/09). SDEU rozhodl, že eBay, jako provozovatel online aukčního portálu je vyňat z odpovědnosti za porušování práv k ochranným známkám na základě aplikace príslušných ustanovení Směrnice 2000/31/ES za podmínky, že nehrál aktivní roli při podpoře prodeje či inzerce prodejců. Zvláštní na postavení společnosti eBay je již zmíněná skutečnost, že totiž $\mathrm{v}$ těchto typech sporů vystupuje ve dvojroli, jednak v roli poskytovatele služeb informační společnosti (hosting) a jednak jako inzerent s ohledem na skutečnost, že provádí také reklamu na zboží prodávané na svém online tržišti zadáváním reklamy prostřednictvím optimalizace internetových vyhledávačů. V uvedeném sporu šlo o výběr klíčových slov odpovídajících mj. ochranným známkám společnosti L’Oreal v rámci optimalizační služby Google AdWords. Prostřednictvím eBay pak byly fyzickými osobami prodávány v EU značkové výrobky L'Oréal určené k prodeji ve třetích zemích a navíc i výrobky, které nejsou určeny k prodeji, 
jako jsou testery a vzorky. Kromě toho některé $\mathrm{z}$ těchto výrobků byly prodávány bez obalu a v několika př́padech se jednalo o prodej padělků. SDEU vycházel z toho, že provozovatel online tržiště je v př́padě zadání klíčových slov do optimalizační služby, inzerentem. Vlastník ochranné známky je proto oprávněn zakázat provozovateli on-line tržiště, aby prostřednictvím klíčového slova, které je totožné s touto ochrannou známkou a které si vybral v rámci služby optimalizace pro vyhledávače na internetu (bez souhlasu vlastníka), prováděl reklamu pro toto tržiště a výrobky označené uvedenou ochrannou známkou, které jsou na tomto tržišti nabízeny. V souladu s rozhodnutím Google v. Louis Vuitton tedy uzavřel, že co se týče reklamy zobrazované na internetu prostřednictvím klíčových slov odpovídajících ochranným známkám, je takové klíčové slovo prostředkem, který je inzerentem uživán ke spuštění zobrazení jeho inzerce, a je tudíž předmětem užívání v obchodním styku.

V tomto kontextu je třeba uvést povinnost průhledného zobrazování inzercí na internetu, která je zdůrazněna, s ohledem na zájmy poctivosti obchodu a ochrany spotřebitelů, v článku 6 směrnice 2000/31/ES. Podle tohoto ustanovení fyzická nebo právnická osoba, na jejíž objednávku obchodní sdělení spadající pod službu informační společnosti probíhá, musí být jasně rozeznatelná. Reklama pocházející od provozovatele on-line tržiště a zobrazovaná provozovatelem internetového vyhledávače musí tudíž $\mathrm{v}$ každém př́padě informovat $\mathrm{o}$ totožnosti uvedeného provozovatele a o skutečnosti, že značkové výrobky, které jsou předmětem inzerce, jsou prodávány prostřednictvím tržiště, které provozuje. Vlastník ochranné známky je tedy oprávněn zakázat provozovateli on-line tržišš̌ provádět prostřednictvím klíčového slova totožného s uvedenou ochrannou známkou, které si tento provozovatel vybral $\mathrm{v}$ rámci služby optimalizace pro vyhledávače na internetu, reklamu pro výrobky označené touto ochrannou známkou, prodávané na uvedeném tržišti, pokud tato reklama běžně informovanému a přiměřeně pozornému uživateli internetu (opět koncept průměrného uživatele internetu) neumožňuje nebo jen stěží umožňuje zjistit, zda uvedené výrobky pocházejí od majitele ochranné známky nebo od podniku, který je s ním hospodářsky propojen, či naopak od třetí osoby.

Podobně jako v př́padech Google v. Louis Vuitton dospěl SDEU k závěru, že provozovatel on-line tržiště neuskutečňuje uživání označení totožných nebo podobných s ochrannými známkami, které se objevují $\mathrm{v}$ nabídkách $\mathrm{k}$ prodeji zobrazovaných na jeho internetových stránkách. Pokud jde ovšem o odpovědnost provozovatele on-line tržiště, dospěl SDEU $\mathrm{k}$ závěru, že pokud provozovatel on-line tržiště poskytuje pomoc, která spočívá zejména $\mathrm{V}$ optimalizaci prezentace dotčených nabídek k prodeji nebo propagaci nabídek, je třeba mít za to, že nezaujímá neutrální postavení ve vztahu mezi dotčeným zákazníkem-prodávajícím a potenciálními kupujícími, ale hraje aktivní roli takové povahy, že je možné konstatovat, že tato data týkající se těchto nabídek zná nebo kontroluje. Pokud jde tedy o uvedené př́ípady, nemůže se dovolávat výjimky $\mathrm{v}$ oblasti odpovědnosti stanovené v článku 14 směrnice 2000/31/ES.

Navíc, s ohledem na cíl sledovaný Směrnicí 2004/48/ES o dodržování práv duševního vlastnictví, který spočívá zejména $\mathrm{v}$ tom, aby $\mathrm{v}$ informační společnosti existovala účinná ochrana duševního vlastnictví (viz v tomto smyslu rozhodnutí Productores de Música de España (Promusicae) v. Telefónica de España SAU (C-275/06) ze dne 29. ledna 2008), SDEU konstatoval, že směrnice přiznaná v souladu s čl. 11 třetí větou vnitrostátním soudům pravomoc nařídit poskytovateli on-line služby, jako je poskytovatel, který zpř́ístupňuje uživatelům internetu on-line tržiště, aby přijal opatř̌ení, jež účinně přispívají nejen k ukončení porušování, ke kterému dochází prostřednictvím tohoto tržiště, ale také k předcházení dalším porušováním. 
V jednom $\mathrm{z}$ dalších sporů, Burberry a dalši v. eBay v roce 2012, odvolací soud v Paříži $\mathrm{v}$ rozhodnutí neshledal důvodným aplikovat na eBay výjimku z odpovědnosti poskytovatelů služeb informační společnosti, protože v souladu s požadavkem SDEU hraje aktivní roli v reklamě na zboží prodávané přes tento internetový aukční portál. Podobně také v rozhodnutí Kasačního soudu v Paříži ve věci $L V M H$ v. eBay (2012) byla konstatována aktivní role a navíc také prokazatelné vědomí o porušování práv k ochranným známkám prodejci, protože jednak eBay obdržela velké množství oznámení o porušování těchto práv a jednak sama zadávala reklamu a jinak podporovala tyto prodeje.

S ohledem na kontradiktorní rozhodnutí francouzských soudů lze identifikovat několik klíčových bodů. Francouzské soudy jsou př́znivější vůči vlastníkům ochranných známek než soudy USA (viz dále Tiffany) a soudy v Německu (Rolex), eBay musí udělat vše co je technicky možné, aby zabránil nabídce zboží porušující práva k ochranným známkám a to nejen v reakci na oznámení takového zboží, ale i preventivně, v rámci programového filtru a požadavkem na certifikáty původu a další identifikaci zboží na aukčním portále.

\section{Rozhodovací praxe soudů v USA}

Postoje soudů USA lze demonstrovat na řešení sporu Tiffany (NJ) Inc. v. eBay Inc. (600 F.3d 93) ze dne 1. dubna 2010. Aukční portál eBay provozuje světově známé on-line tržiště, na kterém jsou zobrazovány inzeráty na výrobky prodávané osobami, které se za tímto účelem v portálu registrovaly a eBay si z uskutečněných transakcí účtuje určitý procentní podíl. Uvedené on-line tržiště umožňuje dražbu nabízeného zboží, příp. prodej bez této dražby. V uvedeném sporu prodávající prostřednictvím elektronické aukce eBay nabízel pod značkou Tiffany stříbrné klenoty, z nichž podstatná část (více než tři čtvrtiny) byly padělky. Podstatnou otázkou tohoto sporu z našeho úhlu pohledu je otázka, jestli je společnost eBay odpovědná za spoluúčast na porušování práv z ochranných známek (např. usnadněním prodeje padělků).

Soud se $\mathrm{v}$ tomto sporu odkázal, v rámci výše zmíněné doktríny sekundární, nepřímé odpovědnosti online tržiště na rozhodnutí ve věci Hard Rock Cafe Licencesing Corp. v. Concession Services, Inc. (955 F.9d 1143). V uvedeném sporu soud prohlásil, že společnost provozující bleší trh nemá povinnost prijímat opatření proti prodeji padělků, tedy preventivně působit za účelem zamezení jejich prodeje. Aby mohla být založena odpovědnost tržiště (at' už offline či online), je nutné prokázat, že v konkrétním případě o porušování ochranných známek byl provozovatel takového tržiště informován a na toto oznámení nereagoval. Za účelem zjištění nepř́imé odpovědnosti soud aplikoval test použitý v př́ípadě Inwood Laboratories v. Ives Laboratories (456 U.S. 844) z roku 1982. Podle tohoto testu bude eBay nepř́mo odpovědný za porušování práv k ochranným známkám, pokud budou splněny tyto dvě podmínky: eBay musí vědět o prrímém porušování práv k ochranným známkám a musí i přes uvedenou znalost pokračovat $\mathrm{v}$ obchodním vztahu s porušovatelem těchto práv. Společnost Tiffany zejména upozorňovala na skutečnost, že společnost eBay věděla nebo měla důvod se domnívat, že prodejci porušují ochrannou známku zboží Tiffany. Soud sice potvrdil, že společnost eBay musela mít obecné povědomí o porušování práv z ochranných známek, nicméně prohlásil, takovéto obecné povědomí za nedostačující k tomu, aby byla společnosti eBay uložena povinnost nápravy daného stavu. Soud vzal navíc v úvahu také skutečnost, že eBay investuje ročně desítky miliónů dolarů za účelem detekce padělků a odstraňování zboží, které porušuje práva k ochranným známkám. Aukční portál eBay navíc spolupracuje s vlastníky ochranných známek, aby nalezli a oznámili podezřelé zboží. Takové jednání eBay je konzistentní i s dříve uvedeným požadavkem na uplatnění výjimky 
$\mathrm{z}$ odpovědnosti $\mathrm{v}$ rámci př́stupu $\mathrm{k}$ zásahům do práv autorským $\mathrm{v}$ Digital Millennium Copyright Act (DMCA).

Stejnou analogii s DMCA aplikoval soud výslovně ve sporu Hendrickson v. eBay (165 F.Supp.2d 1082) v roce 2001, kde eBay prokázal, že přijal podobná opatření, jako jsou požadována $\mathrm{v}$ případě DMCA, konkrétně možnost oznámit porušování práv k ochranným známkám a následné zrušení uživatelského přístupu ke službě eBay. Oblastní soud zde př́ímo aplikoval doktrínu nevinného porušovatele s ohledem na padělané zboží prodané na eBay. Soudce stanovil, že eBay je nevinným porušovatelem ve smyslu 15 USC §1114(2) i když žalobce, vlastník ochranné známky prokázal zásah do práv $\mathrm{k}$ této známce. Důvodem byla skutečnost, že eBay nevěděl o možném porušení práv před tím, než žalobce podal žalobu. Také podle stanoviska tohoto soudu nemohlo být po eBay požadováno, aby monitoroval miliony nových reklam zveřejněných na jeho stránkách každý den.

Lze uzavř́it, že v případě soudů USA, je nutné za účelem sekundární odpovědnosti online aukčních portálů prokázat, že bud' záměrně vyvolaly porušení práv k ochranné známce svými uživateli, nebo umožňovaly př́stup ke svým službám těm uživatelům, o kterých věděly, že porušují tato práva. Přičemž k vědomí o porušování práv $\mathrm{k}$ ochranným známkám nepostačuje pouze obecné povědomí, ale je potřeba, aby byl o konkrétním případu porušování informován.

\section{Závěr}

Rozdíly mezi postoji různých států jsou dány zejména různou právní úpravou ochranných známek a civilní odpovědnosti, jak bylo výše uvedeno, ale zřejmě také různým pohledem na otázku, kdo potřebuje více právní ochranu, jestli vlastníci ochranných známek nebo aukční portály. Svou roli zde hrají zřejmě také národní ekonomické zájmy. Z tohoto úhlu pohledu, rozhodnutí francouzských soudů inklinují více $\mathrm{k}$ ochraně vlastníků ochranných známek, přičemž důvodem může být podle Sounderse a Berger-Waliiserové (2011) skutečnost, že francouzské ochranné známky reprezentují jednu čtvrtinu světové produkce luxusního zboží. Vedle toho v USA představuje elektronický obchod již více než polovinu maloobchodního prodeje a má tendenci dále růst (Zpráva amerického úřadu pro sčítání lidu 1999-2013)³, což reflektují rozhodnutí zbavující aukční portály odpovědnosti za poškozování práv vlastníků ochranných známek.

V otázkách internetových aukčních portálů se silně projevuje střet protikladných principů teritoriální působnosti národních právních řádů a globální dosah internetu. Do popředí tak vystupují problémy s různým př́stupem státních regulací ke stejné otázce. Př́íkladem v kontextu námi analyzovaného problému může být sekundární odpovědnost internetových aukčních portálů. K založení sekundární odpovědnosti vyžadují soudy Německa a USA některou $\mathrm{z}$ forem zavinění nebo konkrétní vědomí o př́mém porušení práv $\mathrm{k}$ ochranným známkám některým z uživatelů portálu. Na rozdíl od toho francouzské soudy pojímají odpovědnost internetových portálů šíreji, nebot' stačí, pokud nezajistí, aby jejich jednání nezabránilo vzniku takových aktivit, které porušují práva jiných s konsekvencemi popsanými výše.

Dopadem různých aplikačních a interpretačních př́istupů a globální uživatelské dostupnosti je skutečnost, že uživatelé aukčních portálů při objednání služby nemusí vědět, že "překračují hranice" (např. přesměrování stránek ebay.cz na ebay.com) a že se na ně tedy může vztahovat

\footnotetext{
${ }^{3}$ Dostupné z http://www.census.gov/retail/index.html [vid. 22.10.2016]
} 
působnost jiného právního řádu. S ohledem na uvedené vzniká zřejmá potřeba harmonizace právní úpravy odpovědnosti internetových aukčních portálů v mezinárodním měřítku. Rozdíly mezi př́stupem německých a francouzských soudů ukazují, že ani stávající evropská harmonizační snaha ne vždy zabrání národním soudům aplikaci a interpretaci práva různými způsoby. Pomoci s překlenutím těchto rozdílů může jednak softwarový filtr, který zachytí alespoň část padělaného zboží v první vlně a oznamovací nástroje $\mathrm{s}$ adekvátní odezvou ze strany internetového aukčního portálu. Nezbytná je také spolupráce vlastníků ochranných známek s těmito portály a př́padná alternativní cesta řešení sporů mezi nimi.

\section{Literatura}

[1] ABEL, A., 1990. Asset Prices Under Habit Formation and Catching Up With the Jones. American Ec onomic Review, 80(2), s. 38-42.

[2] CARROLL, B. A. and A. C. AHUVIA, 2006. Some antecedents and outcomes of brand love. Marketing Letters, 17(2), s. 79-89 [vid. 2016-10-25]. Dostupné z: http://link. springer.com/10.1007/ s11002-006-4219-2.

[3] GROVER, V. and P. RAMANLAL, 2004. Digital economics and the e-business dilemma. Business Horizons, 47(4), s. 71-80 [vid. 2016-10-25]. Dostupné z: http://linkinghub.elsevier.com/ retrieve/pii/S0007681304000503.

[4] JENNINGS, J. S., 1989. Trademark Counterfeiting: an unpublished crime. The Journal of Criminal Law and Criminology, 80(3), s. 805-841.

[5] OTIM, S. and V. GROVER, 2010. E-commerce: a brand name's curse. Electronic Markets, 20(2), s. 147-160 [vid. 2016-10-25]. Dostupné z: http://link.springer.com/10.1007/ s12525-010-0039-6.

[6] SAUNDERS, K. and G. BERGER-WALLISER, 2011. The Liability of Online Markets for Counterfeit Goods: A Comparative Analysis of Secondary Trademark Infringement in the United States and Europe. Northwestern Journal of International Law \& Business, 32(1), s. 37-91.

[7] VETTER, W. and C. J. HILL, 2006. Marketing and the law: the hunt fo onlinetrademark infringers: the internet, gray markets, and law collide. Journal of the Academy of Marketing Science, 34(1), s. 87-88. 